\title{
OPERASIONAL PEMBIAYAAN USAHA SYARIAH DI PT. BPRS KOTA MOJOKERTO SEBAGAI UPAYA MEMPERTAHANKAN NON PERFORMING FINANCING (NPF) 0\%
}

\author{
Sanusi Anwar \\ Mojokerto \\ sanusi.anwar33@gmail.com
}

\begin{abstract}
This study seeks to analyze Sharia Business Financing Operations (PUSYAR) as an effort to maintain 0\% Non-Performing Financing (NPF) at PT. BPRS Mojokerto by taking a case study of the synergy of PT. BPRS Mojokerto, Baznas, Diskoperindag and Sharia Economic Community of Mojokerto, in the period 2012 to 2016. The research methodology used is a qualitative approach using qualitative descriptive analysis techniques. Data collection was carried out by means of field observations, interviews and documentation. Sharia Business Financing Program (PUSYAR) at PT. BPRS Mojokerto has succeeded in channeling financing to UKM and IKM in Mojokerto City from 2012 to 2016, and has succeeded in carrying out its function of channeling financing very well so that there has been no problem financing, and can maintain non-performing financing at zero percent $(0 \%)$. The role of the parties involved greatly influences the success of the program. The findings of this study indicate that financing monitoring contributes to the performance of UMKM, so that awareness arises from UKM to pay installments on time. Financing monitoring carried out by the Bank will contribute to the performance of the UKM business.
\end{abstract}

Keywords: Shariah Business Financing; Non Performing Financing; BPRS Mojokerto.

Abstrak: Penelitian ini berupaya untuk menganalisa Operasional Pembiayaan Usaha Syariah (PUSYAR) sebagai upaya mempertahankan Non Performing Financing (NPF) 0\% di PT. kBPRS Kota Mojokerto dengan mengambil studi kasus sinergi PT. BPRS Kota Mojokerto, Baznas, Diskoperindag dan Masyarakat Ekonomi Syariah Kota Mojokerto, pada periode tahun 2012 sampai dengan tahun 2016. Metodologi penelitian yang digunakan adalah pendekatan kualitatif dengan menggunakan tehnik analisis deskriptif kualitatif. Pengumpulan data dilakukan dengan cara observasi lapangan, wawancara dan dokumentasi. Program Pembiayaan Usaha Syariah (PUSYAR) di PT. BPRS Kota Mojokerto telah berhasil menyalurkan pembiayaan kepada pelaku UKM dan IKM Kota Mojokerto sejak tahun 2012 sampai tahun 2016, dan telah berhasil menjalankan fungsi penyaluran pembiayaan dengan sangat baik sehingga belum terjadi pembiayaan bermasalah, dan dapat mempertahankan Non Performing Financing nol persen (0\%). Peran pihak-pihak yang terlibat sangat berpengaruh besar terhadap keberhasilan program tersebut. Temuan dari penelitian ini menunjukkan bahwa monitoring pembiayaan memberikan kontribusi terhadap Kinerja UMKM, sehingga timbul kesadaran dari

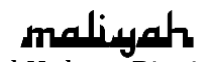

Jurnal Hukum Bisnis Islam

Volume 9 Nomor 2, Desember 2019

p-ISSN: 2088-4869/ e-ISSN: 2597-4351 
UKM untuk membayar angsuran tepat waktu. Monitoring pembiayaan yang dilakukan pihak Bank akan memberikan kontribusi pada kinerja usaha UKM.

Kata Kunci: Pembiayaan Usaha Syariah; Non Performing Financing; BPRS Kota Mojokerto.

\section{Pendahuluan}

Pembangunan ekonomi di Indonesia tidak bisa lepas dari peran aktif pemerintah baik pemerintah pusat atau pemerintah daerah, lembaga perbankan atau lembaga keuangan bukan bank dan pelaku-pelaku usaha itu sendiri. Pemerintah sebagai pihak yang membuat regulasi atau peraturan berupa Undang-undang, Peraturan Pemerintah, Peraturan Menteri dan Peraturan-persturan lain yang dibuat oleh Lembaga Negara ditingkat Pusat atau Daerah, semua itu dengan tujuan untuk mengatur tatanan usaha, perlindungan usaha, kemudahan usaha dan lainnya, dengan harapan bisa memberikan iklim yang positif dan kondusif bagi pelaku usaha, sehingga perbankan atau lembaga keuangan dan pelaku usaha dalam menjalankan usaha dapat terarah dan tidak melanggar hukum atau aturan yang ada disemua tingkatan, sudah barang tentu manfaat regulasi atau kebijakan tersebut akan berdampak pada kegiatan usaha menjadi lancar, kondusif dan pada akhirnya dapat mendorong percepatan serta pertumbuhan pembangunan ekonomi nasional. Dalam praktek bisnis saling melengkapi, mendukung dan kemitraan dari bebagai pihak merupakan suatu keniscayaan agar bisnis berjalan sesuai harapan, karena bisnis itu sendiri merupaka kebutuhan baik individu maupun kelompok/lembaga. ${ }^{1}$

Usaha Mikro, Kecil dan Menengah (UMKM) salah satu pelaku usaha yang memiliki "ketahanan yang luar biasa" pada krisis ekonomi, namun terkadang terlupakan dalam pengambilan kebijakan di negeri ini. Padahal jika kita kenal lebih jauh dan mendalam, posisi dan peran UMKM adalah

\footnotetext{
${ }^{1}$ Nur Ahmad Fadhil and Azhari Akmal, Etika Bisnis Dalam Islam (Jakarta: Hijri Pustaka Utama, 2001).15
} 
sangat strategis, berkontribusi sangat besar dalam mendukung pertumbuhan ekonomi baik di tingkat daerah atau nasional.

Semenjak Indonesia dilanda masa-masa krisis hingga kini, terjadi perubahan yang cukup mendasar di dunia perbankan Indonesia di mana orientasi sebagian dunia perbankan melakukan kemitraan penyaluran kredit/pembiayaan kepada usaha mikro, kecil, dan menengah (UMKM) karena disektor ini masih memiliki ketahanan yang lebih baik dimasa krisis, dari pengalaman ini mendorong reorientasi bisnis perbankan ke sektor UMKM, karena fakta UMKM lebih fleksibel dalam menyikapi setiap perubahan lingkungan usaha. Fakta itu dibuktikan dengan semakin banyaknya bank masuk ke sektor ritel (retail banking business) di mana sektor UMKM menjadi "tulang punggung"-nya.

Namun keberadaan UMKM masih banyak hambatan dan permasalahan yang komplek berkaitan dengan pengembangan usaha UMKM, diantaranya adalah permodalan, Sumber Daya Manusia (SDM) yang masih banyak keterbatasan, akses pasar dan jaringan yang lemah.

Dengan diberlakukannya UU Nomor 23 Tahun 1999 sebagaimana telah diubah dengan UU Nomor 3 Tahun 2004 tentang Bank Indonesia, dimana kebijakan Bank Indonesia dalam mendukung pengembangan UMKM terjadi perubahan paradigma yang cukup mendasar karena Bank Indonesia tidak dapat lagi memberikan bantuan keuangan atau Kredit Likuiditas Bank Indonesia (KLBI), sehingga peranannya untuk mendukung UMKM berubah tidak langsung. Pendekatan yang digunakan kepada UMKM bergeser dari development role menjadi promotional role. Pendekatan yang memberikan subsidi kredit dan bunga murah sudah bergeser kepada pendekatan yang lebih menitikberatkan pada kegiatan pelatihan. Bagi industri Perbankan Syariah, penyaluran pembiayaan yang dilakukan terhadap sektor UKM lebih menguntungkan dibandingkan sektor non UKM. Sektor UKM memiliki ketahanan bisnis lebih kuat, juga faktor pendukung lainnya yaitu kebijakan pemerintah dalam rangka 
pengembangan UKM, baik melalui dinas-dinas pemerintah daerah dalam bentuk pembiayaan, pelatihan ketrampilan atau bantuan peralatan dan sarana prasarana melalui anggaran APBN atau APBD, dengan harapan agar UMKM menjadi tulang punggung perekonomian kita.

Dari uraian tersebut diatas terjadi di semua daerah di Indonesia baik di tingkat Propinsi atau Kabupaten/Kota, oleh karena itu perlu difikirkan program Financial Inclusion yaitu penyediaan akses produk dan jasa keuangan dasar dengan murah, aman dan mudah, khususnya kepada kelompok UKM dan IKM yang masih minim permodalan.

Rupanya Pemerintah Kota Mojokerto dalam rangka pengembangan UKM dan IKM membuat program yang sangat inovatif yaitu Pembiayaan Usaha Syariah PUSYAR, melalui lembaga keuangan di daerah yaitu PT. BPRS Kota Mojokerto, BASNAS Kota Mojokerto, dan secara teknis untuk pengawasan dan pembinaan kepada UKM dan IMK didukung oleh dinas terkait yaitu DISKOPERINDAG dan Masyarakat Ekonomi Syariah (MES), program tersebut untuk menjawab tantangan UKM dan IMK yang selama ini masih sulit untuk mendapatkan sumber modal yang mudah dan murah dari lembaga keuangan perbankan atau lembaga keuangan non bank.

Keberadaan BPR Syariah Kota Mojokerto sebagai lembaga perbankan yang beroperasi dengan system syariah, sangat tepat untuk mendukung program pembiayaan PUSYAR kepada UKM dan IKM dengan menggunakan layanan pembiayaan modal kerja Murabahah dan pola angsuran bulanan. Jika bank syariah memberikan modal kerja dengan akad Murabahah, maka yang dibiayai adalah modal kerja inventori (persediaan barang dagangan sebagai modal kerja). ${ }^{2}$ Realitas program pembiayaan PUSYAR di kota Mojokerto dari tahun ke tahun mengalami pertubuhan yang sangat menggembirakan, disamping pertumbuhan yang tidak kalah pentingnya adalah kualitas pembiayaan yang sangat SEHAT

2 Wiroso, Produk Perbankan Syariah (Jakarta: LPFE Usakti, 2011).224 
dengan indikasi Non Performing Financing (NPF) sampai saat ini masih 0\% (nol persen).

Dari latar belakang dan data di atas, maka peneliti berusaha menganalisis beberapa hal, yakni tentang mekanisme operasional program pembiayaan PUSYAR di PT. BPRS Kota Mojokerto, tentang peranan BAZNAS kota Mojokerto dan PT. BPRS kota Mojokerto dalam program PUSYAR, serta tentang pengawasan program pembiayaan PUSYAR.

\section{Pengertian Bank dan Perbankan Syariah}

Menurut Undang-undang no 21 tahun 2008 Bank adalah badan usaha yang menghimpun dana dari masyarakat dalam bentuk Simpanan dan menyalurkannya kepada masyarakat dalam bentuk kredit dan/atau bentuk lainnya dalam rangka meningkatkan taraf hidup rakyat. Sementara Perbankan Syariah menjadi kebutuhan masyarakat Indonesia yang terus semakin meningkat, dan sejalan dengan tujuan pembangunan nasional Indonesia untuk mencapai terciptanya masyarakat adil dan makmur berdasarkan demokrasi ekonomi, dikembangkan system ekonomi yang berlandaskan pada nilai keadilan, kebersamaan, pemerataan, dan kemanfaatan yang sesuai dengan prinsip-pirinsip syariah. Jadi perbankan syariah adalah segala sesuatu yang menyangkut tentang Bank Syariah dan Unit Usaha Syariah, mencakup kelembagaan, kegiatan usaha, serta cara dan proses dalam melaksanakan kegiatan usahanya.

Bank secara sederhana dapat diartikan sebagai lembaga keuangan yang kegiatan utamanya adalah menghimpun dana dari masyarakat dan menyalurkannya kembali dana tersebut ke masyarakat serta memberikan jasa bank lainnya. ${ }^{3}$

1. Jenis Bank Syariah

Dalam pasal 1 Undang-Undang Nomor 21 Tahun 2008, disebutkan bahwa bank terdiri atas dua jenis, yaitu bank

\footnotetext{
${ }^{3}$ Kasmir, Managemen Perbankan (Jakarta: PT Raja Grafindo Persada, 2000).12
} 
konvensional dan bank syariah. Bank konvensional adalah bank yang menjalankan kegiatan usahanya secara konvensional yang terdiri atas Bank Umum Konvensional dan Bank Perkreditan Rakyat. Bank syariah adalah bank yang menjalankan kegiatan usahanya berdasarkan pprinsip syariah yang terdiri atas Bank Umum Syariah (BUS) dan Bank Pembiayaan Rakyat Syariah (BPRS). Prinsip syariah adalah prinsip hukum Islam dalam kegiatan perbankan berdasarkan fatwa yang dikeluarkakn oleh lembaga yang memilikikewenangan dalam penetapan fatwa di bidang syariah.

BUS adalah bank syariah yang kegiatannya memberikan jasa dalam lalu lintas pembayaran. BPRS adalah bank syariah yang dalam melaksanakan kegiatan usahanya tidak memberikan jasa dalam lalu lintas pembayaran. Unit Usaha Syariah (UUS) adalah unit kerja dari kantor pusat Bank Umum Konvensional yang berfungsi sebagai kantor induk dari kantor atau unit yang melaksanakan kegiatan usaha berdasarkan prinsip syariah, atau unit kerja di kantor cabang dari suatu bank yang berkedudukan di luar negeri yang melaksanakan kegiatan usaha secara konvensional yang berfungsi sebagai kantor induk dari kantor cabang pembantu dan/atau unit syariah.

2. Fungsi Bank Syariah

Berdasarkan Pasal 4 UU Nomor 21 Tahun 2008 tentang Perbankan Syariah, disebutkan bahwa Bank Syariah wajib menjalankan fungsi menghimpun dan menyalurkan dana masyarakat. Bank Syariah juga dapat menjalankan fungsi sosial dalam bentuk lembaga baitul mal, yaitu menerima dana yang berasal dari zakat, infak, sedekah, hibah, atau dana sosial lainnya (antara lain denda terhadap nasabah atau ta'zir) dan menyalurkannya kepada organisasi pengelola zakat. Selain itu, bank syariah juga dapat menghimpun dana sosial yang berasal dari wakaf uang dan menyalurkannya kepada pengelola wakaf (nazhir) sesuai dengan kehendak pemberi wakaf (wakif). 
Dalam beberapa literatur perbankan syariah, bank syariah dengan beragam skema transaksi yang dimiliki dalam skema non-riba memiliki setidaknya empat fungsi, yaitu fungsi manajer investasi; fungsi investor; fungsi sosial; dan fungsi jasa keuangan.

3. Prinsip Penghimpunan Dana Bank Syariah

Penghimpuan dana dari masyarakat yang dilakukan oleh bank konvensional maupun syariah dilakukan dengan menggunakan instrumen tabungan, deposito, dan giro yang secara total biasa disebut dengan dana pihak ketiga. Akan tetapi, pada bank syariah, klasifikasi penghimpunan dana bank syariah tidak didasarkan pada nama instrumen tersebut melainkan berdasarkan pada prinsip yang digunakan. Berdasarkan fatwa Dewan Syariah Nasional (DSN), prinsip penghimpunan dana yang digunakan dalam bank syariah ada dua, yaitu prinsip wadiah dan prinsip mudharabah.

Wadiah berarti titipan dari satu pihak ke pihak lain, baik individu maupun badan hukum yang harus dijaga dan dikembalikan oleh yang penerima titipan, kapan pun si penitip menghendaki. Wadiah dibagi atas dua, yaitu wadiah yad-dhamanah dan wadiah yad-amanah. Wadiah yaddhamanah adalah titipan yang selama belum dikembalikan kepada penitip dapat dimanfaatkan oleh penerima titipan. Apabila dari hasil pemanfaatan tersebut diperoleh keuntungan, maka seluruhnya menjadi hak penerima titipan. Prinsip titipan wadiah yad-amanah adalah penerima titipan tidak boleh memanfaatkan barang titipan tersebut sampai si penitip mengambil kembali titipannya. Prinsip wadiah yang lazim digunakan dalam perbankan syariah adalah wadiah yad-dhamanah dan biasa disingkat dengan wadiah.

Mudharabah adalah perjanjian atas suatu jenis kerja sama usaha dimana pihak pertama menyediakan dana dan pihak kedua bertanggung jawab atas pengelolaan usaha. Pihak yang menyediakan dana biasa disebut dengan istilah shahibul mal, sedang pihak yang mengelola usaha biasa disebut dengan istilah mudharib. Keuntungan hasil usaha 
dibagikan sesuai dengan nisbah bagi hasil yang disepakati bersama sejak awal. Akan tetapi, jika terjadi kerugian, shahibul mal akan kehilangan sebagian imbalan dari hasil kerjanya selama proyek berlangsung.

Berdasarkan PSAK 105, mudharabah dibagi atas tiga, yaitu mudharabah muthlaqah, mudharabah muqayyadah, dan mudharabah musyarakah. Mudharabah muthlaqah adalah mudharabah yang memberi kuasa kepada mudharib secara penuh untuk menjalankan usaha tanpa batas apapun yang berkaitan dengan usaha tersebut. Mudharabah muthlaqah biasa disebut juga dengan investasi tidak terikat. Mudharabah muqayyadah, yaitu shahibul mal, memberi batasan kepada mudharib dalam pengelolaan dana berupa jenis usaha, tempat, pemasok, maupun konsumen. Mudharabah muqayyadah biasa disebut juga dengan investasi terikat.

4. Prinsip Penyaluran Dana Bank Syariah

Penyaluran dana bank syariah dilakukan dengan menggunakan skema jual beli, skema investasi, dan skema sewa. Skema jual beli memiliki beberapa bentuk, yaitu murabahah, salam, dan istishna'. Skema investasi terdiri atas dua jenis, yaitu mudharabah dan musyarakah. Sementara itu, skema sewa terdiri atas ijarah dan ijarah muntahiya bittamlik.

Jual beli dengan skema murabahah adalah jual beli dengan menyatakan harga perolehan dan keuntungan yang disepakati oleh penjual dan pembeli. Skema ini dapat digunakan oleh bank untuk nasabah yang hendak memiliki suatu barang, sedang nasabah yang bersangkutan tidak memiliki uang pada saat pembelian. Pada pembiayaan dengan skema murabahah, bank adalah penjual, sedang nasabah yang memerlukan barang adalah pembeli. Keuntungan yang diperoleh bank dalam pembiayaan ini adalah berupa margin atau selisih barang yang dijual oleh bank dengan harga pokok pembelian barang. secara angsuran kepada bank dalam jangka waktu yang disepakati. 
Jual beli dengan skema salam adalah jual beli yang pelunasannya dilakukan terlebih dahulu oleh pembeli sebelum barang pesanan diterima. Skema ini dapat digunakan oleh bank untuk nasabah yang memiliki cukup dana, sedang yang bersangkutan kurang memiliki bargaining power dengan penjual dibanding dengan sekiranya pembelian barang dilakukan oleh bank. Dalam skema ini, bank sebagai penjual memperoleh keuntungan dari selisih harga jual kepada nasabah dengan harga pokok pembelian barang yang dilakukan pada pemasok.

Jual beli dengaan skema istishna' adalah jual beli yang didasarkan atas penugasan atau pesanan oleh pembeli kepada penjual yang juga produsen untuk menyediakan barang atau suatu produk sesuai dengan spesifikasi yang disyaratkan pembeli dan menjualnya dengan harga yang disepakati. Oleh karena bank hanya sebagai penjual, sedang pembuatan produk dilakukan oleh pihak lain, yaitu produsen, bank juga biasanya melakukan kontrak istishna' dengan produsen untuk membeli produk sebagaimana diinginkan oleh nasabah pembiayaan. Skema double istishna' ini biasa disebut dengan istishna' paralel. Cara pembayaran skema ini dapat berupa pembayaran di muka, cicilan, atau ditangguhkan sampai jangka waktu akad.

Prinsip investasi dalam pembiayaan oleh bank syariah terdiri atas investasi dengan skema mudharabah dan investasi dengan skema musyarakah. Pada dasarnya, penyaluran dana dengan skema mudharabah sama dengan penghimpunan dana. Dalam transaksi penghimpunan, bank adalah mudharib (pengelola dana), sedang nasabah penabung/deposan adalah shahibul mal (pemilik dana). Aakan tetapi, pada transaksi penyaluran dana dengan skema mudharabah, bank bertindak sebagai shahibul mal yang memberi kewenangan kepada mudharib untuk menjalankan usaha tanpa adanya batasan tempat, jenis produk, pelanggan maupun pemasok. Bank memeperoleh pendapatan dari nisbah bagi hasil yang menjadi hak bank. Adapun pada mudharabah muqayyadah, bank hanya berperab sebagai agen yang menghubungkan nasabah pembiayaan mudharabah muqayyadah yang telah menetapkan 
batasan tertentu dalam kegiatan investasi oleh nasabah yang menerima pembiayaan mudharabah muqayyadah. Dari upaya bank memfasilitasi pemilik dana dan pengelola dana mudharabah muqayyadah tersebut, bank memperoleh fee sejumlah tertentu yang telah disepakati.

Investasi dengan skema musyarakah adalah kerja sama investasi para pemilik modal yang mencampurkan modal mereka pada suatu ussaha tertentu dengan pembagian keuntungan berdasarkan nisbah yang telah disepakati sebelumnya, sedangkan apabila terjadi kerugian ditanggung semua pemilik modal berdasarkan porsi modal masing-masing. Pada skema ini, hubungan antara bank dengan nasabah pembiayaan adalah hubungan kemitraan sesama pemilik modal. Dalam hal ini, bank dan mitra sama-sama menyediakana modal untuk membiayai suatu usaha tertentu, baik yang sudah berjalan maupun yang baru berjalan. Selanjutnya, mitra dapat mengembalikan modal tersebut beserta bagi hasil yang telah disepakati nisbahnya secara bertahap atau sekaligus kepada bank.

Prinsip sewa terdiri atas dua skema, yaitu skema ijarah dan skema ijarah muntahiya bittamlik. Sewa dengan skema ijarah adalah transaksi sewa-menyewa antara pemilik objek sewa dan penyewa untuk mendapatkan imbalan atas objek sewa yang disewakan. Dalam transaksi sewa dengan skema ijarah, bank adalah pemilik objek sewa, sedang nasabah adalah penyewa. Transaksi ini dapat diterapkan bank pada nasabah yang hanya menginginkan manfaat dari objek sewa yang disediakan bank dan tidak untuk memilikinya. Skema ini oleh perbankan syariah dapat dipergunakan untuk keperluan sewa barang maupun sewa jasa. Beberapa bank belakangan ini mulai menggunakan skema ini untuk memfasilitasi nasabah membiayai kebutuhannya terhadap jasa pendidikan, kesehatan, dan bahkan aktivitas rekreasi yang memerlukan biaya tertentu. Dengan skema ini, nasbah difasilitasi oleh bank untuk menggunakan jasa kesehatan di rumah sakit, jasa pendidikan di suatu institusi pendidikan, ataupun jasa rekreasi melalui biro perjalanan. Selanjutnya, atas penggunaan fasilitas tersebut, 
nasabah membayar kepada bank baik secara tunai maupun secara angsuran. Sewa dengan skema ijarah muntahiya bittamlik adalah transaksi sewa-menyewa antara pemilik objek sewa dan penyewa untuk mendapatkan imbalan atas objek sewa yang disediakannnya dengan opsi perpindahan hak milik pada saat tertentu sesuai dengan akad sewa. Berbeda dengan transaksi ijarah, transaksi ijarah muntahiya bittamlik memberi hak pilih pada penyewa untuk memiliki barang yang disewa.

\section{PT. BPRSyariah Kota Mojokerto.}

PT. BPR Syariah Kota Mojokerto sebagai perusahaan milik pemerintah daerah sudah barang tentu sebagai bagian organ pemerintah daerah yang harus ikut mendukung program-program pemerintah kota disegala bidang terutama sektor keuangan dan perekonomian daerah, PT. BPRS Kota Mojokerto sebagai perusahaan daerah yang pembinaannya dilakukan pemerintah kota, juga dilakukan oleh Kementrian Dalam Negeri dengan Permendagri No. 22 tahun 2006 tentang Pengelolaan Bank Perkreditan Rakyat Milik Pemerintah Daerah.

Semenjak dikeluarkannya Undang-Undang No. 22 tahun 1999 tentang Pemerintah Daerah dan Peraturan Pemerintah No. 25 tentang Kewenangan Pemerintah dan Kewenangan Propinsi sebagai daerah otonom, maka kewenangan otonom saat ini telah diserahkan kepada daerah. Kewenangan tersebut mencakup penanganan segala urusan rumah tangga daerah sebagai lembaga berikut perangkatnya.

Serta untuk meningkatkan dan mendayagunakan potensi ekonomi daerah dalam rangka meningkatkan pendapatan Asli Daerah (PAD), Pemerintah Kota Mojokerto sangat memerlukan peran lembaga keuangan yang diharapkan dapat memenuhi tujuan tersebut. Dimana pada gilirannya Lembaga Keuangan tersebut diharapkan dapat meningkatkan dan mendayagunakan perekonomian daerah guna mencapai kesejahteraan masyarakat daerah secara merata. Bentuk lembaga keuangan yang sesuai dengan kondisi daerah Kota 
Mojokerto yang sangat ideal adalah Lembaga Keuangan Mikro, dalam hal ini adalah Bank Pembiayaan Rakyat Syari'ah (BPRS).

PT. Bank Pembiayaan Rakyat Syariah Kota Mojokerto senantiasa berupaya untuk tetap eksis dalam memberikan pelayanan terbaik bagi seluruh nasabah khususnya maupun seluruh lapisan masyarakat Mojokerto dan sekitarnya secara umum, PT. BPRS Kota Mojokerto juga harus mampu mengikuti perkembangan-perkembangan yang ada saat ini.

Namun, dengan adanya keterbatasan sumber daya dan sumber pendanaan maka perlu dilakukan analisa penyerapan dari pendanaan yang ada serta sumber pendanaan sendiri dari nasabah yang sudah ada maupun pengembangan kedepannya. Perlu dilakukan peningkatan pengelolaan perusahaan dengan sistem manajemen yang baik dan profesional agar dapat memenuhi kebutuhan stakeholders sehingga tujuan dari peningkatan ekonomi masyarakat Mojokerto dan sekitarnya dapat dicapai, khususnya pegiat UKM dan IKM.

Untuk itu, diperlukan penyusunan program-program kerja, anggaran dan perencanaan strategis yang terpadu agar dapat digunakan oleh pihak manajemen sebagai bahan referensi dalam pengambilan keputusan dan pengembangan perusahaan. Program-program dan perencanaan tersebut berguna untuk memberikan arah terhadap perkembangan dan perbaikan perusahaan.

1. Rencana Operasional

Rencana Operasional merupakan langkah-langkah implementasi dari strategi yang dinyatakan dalam bentuk kegiatan-kegiatan. Rencana Operasional memuat Rencana Kerja berdasarkan kegiatan-kegiatan yang dialokasikan sesuai dengan waktu pelaksanaan dan anggaran. Berdasarkan kegiatan-kegiatan tersebut, PT. BPRS kota Mojokerto bisa menganalisa kebutuhan sumber daya dan membangun strategi pendanaan.

Berdasarkan misi dan visi, BPRS Kota Mojokerto membangun strategi ekspansi berdasarkan penilaian internal dan penilaian eksternal institusi (atau lebih dikenal 
sebagai analisa SWOT - Strengths-WeaknessesOpportunities-Threats). Selanjutnya, dalam menjalankan strategi tersebut, BPRS Kotsa Mojokerto perlu menetapkan sasaran utama dan tujuan sebagai bagian dari langkahlangkah pelaksanaan (implementasi) strategi. Tahaptahapan implementasi strategi:

a. Sasaran Utama dan Tujuan

b. Ukuran, program dan kegiatan-kegiatan

Tahapan dan langkah-langkah implementasi visi dan misi tersebut menjadi dasar pembuatan Rencana Operasional, yang mencakup aspek-aspek:

a. Produk dan jasa

b. Saluran distribusi pemasaran

c. Kebutuhan sumber daya

d. Manajemen pendanaan

e. Rencana operasional tahunan

2. Rencana Finansial

Rencana Finansial merupakan penjabaran dari strategi dan dibuat bersamaan dengan Rencana Operasional. Rencana Finansial dan Rencana Operasional berkaitan erat satu sama lain di mana Rencana Operasional menjabarkan kegiatan-kegiatan yang akan dilakukan dalam mengimplementasikan strategi dan Rencana Finansial menjabarkan pendanaan untuk kegiatan-kegiatan tersebut.

Rencana Finansial diawali dengan Strategi Finansial. Strategi Finansial merupakan bagian dari Rencana Strategis dan berkaitan dengan usaha meningkatkan pertumbuhan portfolio dan peningkatan saldo Dana Pihak Ketiga. Dalam hal ini, Strategi Finansial juga berfungsi sebagai "Road Map" dan "Management Tools". Strategi Finansial merupakan dan dibuat berdasarkan 2 skenario:

a. Pasar yang sekarang

b. Pasar yang akan dimasuki (dalam ekspansi pasar)

Tujuan Strategi Finansial:

a. Meningkatkan pertumbuhan portfolio pembiayaan

b. Meningkatkan mobilisasi Dana Pihak Ketiga yang relatif murah 

c. Memperluas daerah operasi/ jangkauan / bekerja
d. Meningkatkan profitabilitas

3. Komunikasi dan Sosialisasi Rencana Bisnis

Perencanaan Usaha (Business Plan) yang terdiri dari Rencana Strategis, Rencana Operasional dan Rencana Finansial perlu dikomunikasikan kepada seluruh manajemen dan karyawan perusahaan di setiap tingkatan untuk mendapatkan dukungan dan komitmen mereka. Hal ini perlu karena setiap orang dalam perusahaan perlu memahami rencana usaha tersebut dan peranan mereka masing-masing. Setiap orang dalam perusahaan perlu melaksanakan Rencana Usaha dan diwujudkan dalam kegiatan mereka sehari-hari. Pembuatan Perencanaan Usaha yang melibatkan semua orang, baik dari pihak manajemen maupun karyawan, dalam setiap langkah pembuatannya merupakan bagian dari proses komunikasi.

a. Proses komunikasi bisa dilakukan melalui berbagai media:

1) Dalam setiap meeting dan pertemuan rutin yang diselenggarakan oleh perusahaan

2) Jaringan komunikasi di dalam (LAN, email)

3) Presentasi oleh tim penyusun

4) Brosur / buletin / edaran internal

5) Booklet Rencana Usaha dicetak / di foto kopi dan dibagikan ke pada semua orang

6) Visi dan Misi dipajang di dinding dan diletakkan di tempat-tempat yang strategis dalam kantor

7) Perkembangan pelaksanaan strategi diumumkan dalam meeting, surat edaran dan kegiatan-kegiatan lain dalam perusahaan

b. Proses Komunikasi yang terencana

Dengan melibatkan semua orang, akan terbangun rasa memiliki terhadap Rencana Usaha. Komunikasi merupakan proses yang interaktif (dua arah) di mana semua orang dalam tingkatan organisasi dapat menyumbangkan ide-ide mereka. Seringkali ide-ide yang bagus datang dari orang yang tidak terduga dan bisa 
terjadi di semua lapisan. Karena itu proses komunikasi sebaiknya dibuat secara terstruktur dan terencana. Langkah-langkah proses komunikasi:

1) Tugaskan tim penyusun rencana usaha untuk turun ke semua tingkatan dalam organisasi dan membuat meeting untuk membahas dan meminta masukan untuk perbaikan dan masukan mengenai kemajuan pelaksanaan. Dalam pertemuan ini, setidak-tidaknya peserta dapat mengenal dan memahami visi, misi dan strategi agar mereka dapat menyelaraskan tugas dan pekerjaan mereka dengan Rencana Usaha.

2) Dalam pertemuan ini, setiap bagian dalam organisasi dapat diminta untuk membuat Rencana Usaha di tingkatan mereka.

3) Pastikan bahwa proses yang dibuat di setiap bagian dan tingkatan terkait dan terintegrasi secara menyeluruh dengan Rencana Usaha perusahaan.

4) Setelah bertemu dengan setiap bagian, selenggarakan meeting untuk mempertemukan semua orang agar semua bisa memberikan masukan bagi usulan yang diajukan oleh bagian lain.

5) Proses di atas disebut juga dengan proses bertingkat (cascading). Proses bertingkat ini sangat membantu dalam.

6) Menjembatani kekurangan atau kelemahan komunikasi dalam struktur perusahaan.

7) Menyediakan informasi terkini yang dibutuhkan dalam pembuatan keputusan oleh manajemen.

8) Adanya visi dan misi membuat karyawan memiliki jati diri yang lebih jelas dalam kaitan dengan pekerjaan yaitu dengan mengetahui peranan dan sumbangan yang dapat mereka berikan ke pada masyarakat

9) Setiap orang memiliki kesempatan untuk menyumbang dan berpartisipasi dalam keberhasilan perusahaan

4. Sumber Daya Manusia PT. BPRS Kota Mojokerto

Struktur organisasi sudah mengakomodir kondisi kebutuhan operasional saat ini, Masing-masing bagian telah 
memiliki job description sesuai dengan tugas dan fungsinya. Sistem rekuitmen pegawai melalui mekanisme penerimaan pegawai yang diumumkan di radio dan Koran. Sedangkan untuk pendidikan dan pelathan setiap tahun dianggaran $5 \%$ dari total biaya personalia tahun lalu untuk biaya pendidikan yang dkerjasamakan dengan lembaga pendidikan dan konsultan seperti LPPI, Asbisindo dan lembaga-lembaga pendidikan yang berkaitan dengan Perbankan.

Adminsitrasi kepegawaian mulai dari absensi dengan sistem sidik jari (fingerprint) dan system penggajian yang terintegrasi dengan rekening tabungan masing-masing pegawai. Sistem Akuntasi dan MIS yang digunakan telah terintegrasi dari front office sampai back office sampai tahap pelaporan.

5. Tehnologi Informasi

Sistem MIS yang telah ada saat ini sudah memenuhi kebutuhan mulai dari tabungan, deposito, pembiayaan (core banking) dan laporan keuangan (neraca, laba rugi, arus kas, buku besar dll) yang kesemuanya dikontrol oleh bagian resident auditor sebagai internal control pada system dan prosedur.

6. Manajemen Keuangan

Laporan Keuangan setiap bulan selalu dilaporkan kepada Komisaris, Bank Indonesia dan triwulan dipublikasikan kepada masyarakat melalui papan pengumuman, Koran local dan website. Secara berkala dilakukan peninjauan antara anggaran tahunan dengan realisasi anggaran dan dilakukan evaluasi terhadap pencapaian tersebut. Ratio keuangan selalu dipantau utamanya pada Cash Ratio yang setiap saat dilakukan pengecekan untuk memastikan cadangan likuiditas tetap terjaga.

\section{Pengembangan UKM dan IKM melalui Pembiayaan Usaha Syariah (PUSYAR) di Kota Mojokerto.}


Peran pemerintah Kota Mojokerto dalam rangka mengembangkan UKM dan IKM memang sangat diperlukan. Karena UKM dan IKM merupakan salah satu usaha yang potensial untuk meningkatkan perekonomian serta meningkatkan kesejahteraan masyarakat. Sehingga perlu adanya keberpihakan dalam rangka pemberdayaannya, baik dari segi sumber daya manusia sampai pada pengadaan sarana dan prasarana serta permodalan yang terjangkau oleh mereka.

UKM dan IKM secara umum sangat banyak memberi manfaat dalam sektor ekonomi dan sosial di suatu daerah, yaitu dapat menyerap banyak tenaga kerja serta mengurangi tingkat pengangguran, sebagai berikut:

1. Peranan UMKM di Bidang Ekonomi

Usaha Mikro, Kecil, dan Menengah (UMKM) mempunyai peranan yang sangat strategis dalam pembangunan ekonomi nasional. Selain berperan dalam pertumbuhan ekonomi dan penyerapan tenaga kerja, UMKM juga berperan dalam pendistribusian hasil-hasil pembangunan. UMKM diharapkan mampu memanfaatkan sumber daya nasional, termasuk pemanfaatan tenaga kerja yang sesuai dengan kepentingan rakyat dan mencapai pertumbuhan ekonomi yang maksimum. UMKM telah menunjukkan peranannya dalam penciptaan kesempatan kerja dan sebagai salah satu sumber penting bagi pertumbuhan Produk Domestik Bruto (PDB).

2. Peranan UMKM di Bidang Sosial

UMKM mampu memberikan manfaat sosial yaitu mereduksi ketimpangan pendapatan, terutama di negara- negara berkembang. Peranan usaha kecil tidak hanya menyediakan barang-barang dan jasa bagi konsumen yang berdaya beli rendah, tetapi juga bagi konsumen perkotaan lain yang berdaya beli lebih tinggi. Selain itu, usaha kecil juga menyediakan bahan baku atau jasa bagi usaha menengah dan besar, termasuk pemerintah lokal. Tujuan sosial dari UMKM adalah untuk mencapai tingkat kesejahteraan minimum, yaitu menjamin kebutuhan dasar rakyat. "Tujuan mulia yang ingin dicapai sektor publik, yaitu kesejahteraan 
sosial (social welfare) dengan sendirinya menuntut tata kelola pemerintahan yang baik (good governance). Saat ini tuntutan agar pemerintah mampu secepatnya merealisasikan pencapaian kesejahteraan sosial semakin besar.

Dalam hal ini peran Diskoperindag Kota Mojokerto merupakan kepanjangan tangan dari Pemerintah Daerah untuk membantu mengatasi permasalahan yang terjadi dalam pengembangan UMKM, seperti bidang produksi dan pengolahan, pemasaran, sumber daya manusia, serta desain dan teknologi.

\section{Pembinaan dan Pelatihan UKM dan IKM}

Dari hasil wawancara dengan Ibu Aris, Diskoperindag Kota Mojokerto mempunyai tugas dan tanggung jawab Pembinaan dan pelatihan yang dilakukan oleh Diskoperindag Kota Mojokerto merupakan wujud pemberdayaan sebagai motivasi atau dorongan bagi UKM dan IKM secara khususu dan kepada masyarakat secara umum untuk mengasah kemampuan yang mereka miliki serta dapat menjadikan bekal ilmu pengetahuan dan keterampilan bagi masyarakat yang ingin membuka usaha sendiri. Dalam mengatasi permasalahan yang dihadapi oleh UMKM, Diskoperindag menyediakan pelayanan seperti Klinik UMKM yang bekerjasama dengan pemerintah provinsi Jawa Timur. Di Klinik UMKM, calon maupun pengusaha UMKM terutama untuk pengembangan usahanya dapat berkonsultasi mengenai rencana atau pengembangan usaha yang dijalankannya.

Keterbatasan SDM pengusaha UKM dari segi pendidikan formal maupun pengetahuan dan keterampilannya sangat berpengaruh terhadap manajemen pengelolaan usahanya, termasuk minimnya pengetahuan mengenai teknologi akan menyulitkan mereka dalam meningkatkan daya saing produk yang dihasilkan sehingga usaha tersebut sulit untuk berkembang dengan optimal. Oleh karena itu betapa pentingnya program pembinaan dan pelatihan yang dilakukan oleh Diskoperindag Kota Mojokerto ini sangat berguna untuk 
memberikan bekal ilmu pengetahuan dan keterampilan dalam mengembangkan usaha yang dijalankannya. Dalam pembinaan dan pelatihan UKM dan IKM ada beberapa hal yang menjadi perioritas, antara lain:

1. Peningkatan Promosi produk

Dalam hal ini kegiatan peningkatan promosi produk yang dilakukan oleh Diskoperindag yaitu berupa kegiatan seperti bazar atau pameran UMKM. Selain itu, kegiatan ini biasanya diadakan di luar kota bahkan sampai ke luar pulau, kegiatan ini juga bekerjasama dengan pemerintah provinsi Jawa Timur untuk mempermudah suatu wilayah dalam bekerjasama dengan provinsi lain. Diskoperindag Kota Mojokerto dalam hal ini melakukan kegiatan promosi produk rutin setiap tahun dengan lokasi yang berbeda-beda. Dengan keanekaragaman lokasi serta peserta UMKM dari seluruh penjuru di Indonesia, hal tersebut bermanfaat untuk memperluas jaringan pema saran UMKM sampai ke tingkat internasional.

2. Akses Pemasaran Produk.

Secara umum pemasaran produk UMKM memiliki lokasi yang saling berdekatan. Produk yang dihasilkan pun juga terkadang sama. Oleh karena itu, persaingan di dalam pemasaran produknya merupakan hal yang wajar terjadi. Sebenarnya hal ini tidak perlu terjadi jika pengusaha UKM mampu meningkatkan kreativitas mereka dengan memproduksi varian produk yang berbeda, tetapi masih dari bahan baku yang sama. Karena dengan adanya persaingan seperti itu mereka akan semakin sulit untuk memasarkan hasil produknya. Inilah yang menjadi kendala mereka di dalam memasarkan hasil produknya.

3. Permasalahan dalam Permodalan

Modal adalah faktor terpenting dalam membuka usaha. Karena UMKM merupakan usaha rumahan yang mengandalkan modal sendiri, maka dalam permodalan ini memerlukan bantuandan keberpihakan dari pemerintah.

\section{Akses Permodalan bagi UKM dan IKM.}


Pada umumnya UKM dan IKM dalam menjalankan bisnisnya dengan mengandalkan pada modal sendiri yang relative kecil, sehingga untuk mengembangkan usaha sangat lambat, disisi lain perlu peningkatan produk karena permintaan pelanggan atau ingin mengembangkan pasar, permasalah ini kadang menjadi alasan yang mendasar bagi UKM dan IKM yang memaksa mereka terjebak keterikatan dengan rentenir. Semua itu dikarenakan masih rendah dan terkadang sulit untuk mengakses terhadap sumber-sumber pembiayaan formal, karena sebagian besar mereka tidak mempunya persyaratan sebagai pengusaha yang bankable, tidak jarang mereka harus mencari sumber-sumber permodalan dengan bunga yang tinggi yang tidak syariah, seperti renternir, koperasi simpan pinjam konvensional dan sumber-sumber lain.

Gagasan mulia pemerintah Kota Mojokerto yang sangat inovatif dengan membuat program pengembangan UKM dan IKM yang ada di Kota Mojokerto untuk mempermudah akses permodalan ke perbankkan, sehingga harus membentuk satuan kerja khusus dalam mendukung program tersebut. Pemerintah Kota Mojokerto menunjuk PT. BPRS Kota Mojokerto, sebagai perusahaan daerah Kota Mojokerto mempunyai posisi sangan setrategis dan sangat menguntungkan dalam mendukung program pusyar dengan menyediakan pembiayaan modal kerja bagi UKM dan IKM.

Program PUSYAR adalah Pembiayaan Usaha Syariah yang dikhususkan untuk UKM dan IKM Kota Mojokerto juga sebagai program andalan Pemerintah Kota Mojokerto yang bersifat khusus karena implementasinya tidak seperti pembiayaan pada umumnya. Tujuan pelaksanaan program PUSYAR agar UKM dan IKM bisa berkembang dan tumbuh berkat fasilitas pembiayaan yang murah, dengan harapan bisnis UKM dan IKM akan tumbuh sehingga bisa mengembalikan pembiayaan tepat waktu, tidak terjadi pembiayaan bermasalah, yang pada akhirnya tidak terjadi Non Performing Financing (NPF) di PT. BPRS Kota Mojokerto. 
Operasional Kerjasama program pembiayaan usaha syariah melibatkan beberapa lembaga yang diataur dalam nota kesepahaman antar lembaga, antara lain:

1. Perjanjian Kerjasama antara PT. Bank Pembiayaan Rakyat Syariah Kota Mojokerto dengan Badan Amil Zakat Nasional Kota Mojokerto, Nomor : 02/B/417.602/V/2016, 0898/BAZNAS KOTA.MR/V/2016, tanggal, 16 April 2016, tentang Pelaksanaan Program Pembiayaan Usaha Syariah (PUSYAR) Bagi Usaha Kecil Menengah dan Industri Kecil Menengah Kota Mojokerto.

2. Nota Kesepahaman antara Bank Pembiayaan Rakyat Syariah Kota Mojokerto dengan Badan Amil Zakat Nasional Kota Mojokerto, Dinas Koperasi, Perindustrian dan Perdagangan Kota Mojokerto, dan Lembaga Masyarakat Ekonomi Syariah Kota Mojokerto, Nomor : 025/B/417.602/V/2016, Nomor: 897/BAZNAS KOTA.MR/V/2016, Nomor: 188.4/1014/417.305/2016, dan Nomor : 01/MoU/IV/MES/2016.

\section{Peran Masing-masing Lembaga}

Pihak BPRS Kota Mojokerto selaku penyedia dana memberikan fasilitas pembiayaan kepada debitur UKM dan IKM Kota Mojokerto dengan plafon Rp 750.000,- sampai $\mathrm{Rp}$ 10.000.000,- untuk PUSYAR jilid I, dan plafon PUSYAR jilid II, sebesar Rp. 10.000.000,- lebih sampai dengan maksimal Rp. 50.000.000,- dengan menggunakan akad Murabahah. Pembiayaan pusyar akan diproses lebih lanjut apabila sudah mendapatkan rekomendasi dari Dikoperindag dan BAZNAS Kota Mojokerto. Apabila dalam proses analisa ternyata menurut bank tehnis tidak memenuhi syarat untuk di realisasi atau plafon di turunkan dari sesuai kapasita dan kemampuan calon nasabah, persetujuan realisasi pembiayaan tidak ditentukan oleh rekomendasi dari Diskoperindag atau BAZNAS, tetapi dari hasil analisa bank. Realisasi pembiayaan PUSYAR di BPRS Kota Mojokerto per tahun besarnya disesuaikan dengan anggaran dari BAZNAS Kota Mojokerto, karena berkaitan dengan kemampuan anggaran BAZNAS untuk pembayaran margin dan biaya yang lain. 
Pihak BAZNAS Kota Mojokerto, setelah mendapatkan tembusan rekomendasi dari pihak Dikoperindag, maka BAZNAS akan membuat rekomendasi yang sama atas persetujaun pengajuan pembiayaan calaon debitur program pusar tersebut, sebagai tanggung jawab utama BAZNAS menanggung semua biaya marjin pembiayaan atas tagihan dari BPRS Kota Mojokerto bagi debitur yang sudah membayar pokok, termasuk juga tagiahan biaya administrasi dan biaya asuransi debitur program PUSYAR yang selanjutnya BPRS akan membayarkan ke pihak perusahaan asuransi sebagai premi asuransi jiwa.

Pihak Diskoperindag Kota Mojokerto berkewajiban melakukan evaluasi apakah UKM dan IKM calon debitur PUSYAR masih menikmati fasilitas pembiayaan program dari Diskoperindag atau bahkan punya tunggakan fasilitas program. Apabila tidak ada fasilitas atau tunggakan pembiayaan program Diskoperindag, maka dalam hal ini pihak Diskoperindag Kota Mojokerto akan menerbitkan surat rekomendasi calon debitur tersebut untuk diproses lebih lanjut oleh BPRS Kota Mojokerto.

Pihak MES Kota Mojokerto berkewajiban melakukan pengawasan terhadap usaha debitur program PUSYAR dan pembinaan terhadap UKM dan IKM baik dibidang bisnis maupun spiritual kepada mereka, termasuk pembinaan dalam hal manajemen usaha. Akses terhadap sumber pendanaan bagi UKM dan IKM, Pemerintah Kota Mojokerto menunjuk PT. BPRS Kota Mojokerto, sebagai perusahaan daerah Kota Mojokerto untuk menyediakan pembiayaan modal kerja bagi UKM dan IKM. PT. BPRS Kota Mojokerto mendapat peranan yang sangat strategis dan sangat menguntungkan, antara lain adalah meningkatnya porto folio pembiayaan murabahah; risiko pembiayaan bermasalah lebih kecil dibandingkan pembiayaan yang umum; keuntungan akan meningkat seiring pertumbuhan pembiayaan usaha syariah, karena risiko tunggakan sangat kecil; cover asuransi jiwa bagi debitur UKM dan IKM; dan memaksimalkan kemitraan dengan UKM dan IKM, untuk prospek funding. 


\section{Transaksi Pembiayaan Usaha Syariah (PUSYAR)}

Realisasi transaksi pembiayaan Program PUSYAR di mulai bulan April tahun 2012. Seiring dengan berjalannya waktu, program PUSYAR semakin dikenal oleh masyarakat Kota Mojokerto, terutama pengusaha UKM dan IKM. Sejak tahun 2012 sampai dengan tahun 2016 realisasi pembiayaan pusyar mengalami pertumbuhan yang sangat menggembirakan, dari skema yang dijalankan pada program ini hasilnya sangat bagus karena nasabah yang terjaring benarbenar memenuhi kreteria C5 plus Constrain, sehingga terlihan pada kualitas pembiayaan yang sangat SEHAT dengan indikasi Non Performing Financing (NPF) sampai akhir tahun 2016 masih 0\% (nol persen).

Prestasi keberhasilan pembiayaan pusyar dalam mempertahankan kualitas pembiayaan yang SEHAT, tidak terlepas dari peran para pihak yang terlibat dalam proses program pembiayaan usaha syariah, dan yang paling menentukan adalah kesadaran para debitur yang mendapatkan fasilitas PUSYAR. Realisasi Program PUSYAR peran pengendalian yang dilakukan beberapa lembaga yang ditunjuk sebagaiman sangat efektif, karena peran masing-masing dijalankan sebagaimana dalam Nota Kesepahaman antara PT. BPRS Kota Mojokerto, BAZNAS Kota Mojokerto, Diskoperindag Kota Mojokerto dan Masyarakat Ekonomi Syariah (MES) Kota Mojokerto. Pihak BAZ Kota Mojokerto membayar margin, biaya administrasi, dan asuransi pembiayaan kepada BPR Syariah. Pihak Diskoperindag berkewajiban menyeleksi UKM dan IKM calon peserta program PUSYAR dan menetapkannya sebagai peserta program PUSYAR serta melakukan pembinaan, monitoring dan evaluasi terhadap UKM dan IKM peserta program PUSYAR. Dan yang terakhir pihak Masyarakat Ekonomi Syariah (MES) Kota Mojokerto membina UKM dan IKM peserta program PUSYAR dalam hal manajemen usaha, pengawasan dan pemasaran yang berbasis syariah.

\section{Monitoring Pembiayaan Usaha Syariah}


Monitoring dapat diartikan sebagai alat yang dipergunakan untuk melakukan pemantauan pembiayaan, agar dapat diketahui sedini mungkin (early warning system) deviasi yang terjadi yang akan membawa akibat turunnya mutu pembiayaan. ${ }^{4}$

1. Fokus monitoring pembiayaan dilakukan dalam rangka penjagaan dan pengamanan atas pengelolaan kekayaan Bank yang lebih baik dan efisien, guna untuk menghindari terjadinya penyimpangan-penyimpangan dengan cara mendorong dipatuhinya kebijakan pembiayaan yang telah ditetapkan sehingga pembiayaan digunakan sesuai dengan tujuan transaksinya.

2. Pelaksanaan monitoring oleh pihak bank akan dilakukan dalam rangka monitoring usaha dan keuangan usaha secara berkala. Kegiatan pengawasan dan pembinaan pembiayaan dilakukan secara teratur dan berkesinambungan agar tidak terjadi hal-hal yang dapat merugikan bank sehingga dampaknya diharapkan peningkatan frekuensi kunjungan ke debitur dalam rangka pengawasan dan pembinaan debitur.

Frekuensi monitoring yang dilakukan bank diharapkan dapat mondorong pertumbuhan kinerja usaha UMKM. Kegiatan pembinaan dilakukan secara berkesinambungan setelah pembiayaan dicairkan serta frekuensi kunjungan untuk pembinaan perlu ditingkatkan dengan Dalam hal pengawasan yang telah dilaksanakan oleh petugas marketing / account officer PT. BPRS Kota Mojokerto sudah dilakukan secara maksimal mengingat pembiayaan PUSYAR ini adalah bagian dari amanat dari masyarakat yang membayar infak sedekah melalui BAZNAS Kota Mojokerto, terlepas dari semua itu bahwa organisasi dalam menjalankan operasionalnya tentu melalui proses perencanaan, pelaksanaan, pengawasan, dan evaluasi. Begitu juga dalam pelaksanaan program PUSYAR juga dibutuhkan perencanaan yang matang, pelaksanaan, pengawasan, dan evaluasi. Perencanaan dan pelaksanaan

${ }^{4}$ Veithzal, Islamic 488. 
Operasional Pembiayaan Usaha Syariah di PT. BPRS Kota Mojokerto Sebagai ...

program PUSYAR sudah tercapai dan tahap selanjutnya adalah pengawasan.

\section{Penutup}

Berdasarkan hasil penelitian dan analisis yang telah dilakukan, peneliti dapat menyimpulkan bahwa Implementasi program Pembiayaan Usaha Syariah (PUSYAR) Kota Mojokerto mulai dari awal diluncurkan pada tahun 2012, cukup memberi manfaat bagi pengembangan UKM dan IKM di Kota Mojokerto. Komitmen Pemerintah Kota Mojokerto yang sangat tinggi dalam rangka mengembangkan UKM dan IKM dengan permodalan yang murah, yaitu dengan inovasi pembiayaan PUSYAR.

Mekanisme yang telah dilakukan dalam mengamankan pembiayaan program tersebut sangat bagus dan sangat strategis karena terintegrasi antar lembaga yang mempunyai komitmen dan sesuai tugas dan kewenangan masing-masing. UKM dan IKM di Kota Mojokerto sangat potensial sekali karena beragam produk yang dihasilkan, namun semua belum dapat dilayanai dengan fasilitas pembiayaan pusyar tersebut, mengingat keterbatasan pendaan/anggaran dari BAZNAS Kota Mojokerto. Nasabah debitur yang dilayani saat ini rata-rata mempunyai komitmen yang tinggi atas fasilitas pembiayaan yang diterima, sampai dengan tahun 2016 belum ada yang bermasalah, dengan predikat pembiayaan SEHAT, Non Performing Financing $0 \%$.

\section{Daftar Pustaka}

Fadhil, Nur Ahmad, and Azhari Akmal. Etika Bisnis Dalam Islam. Jakarta: Hijri Pustaka Utama, 2001.

Kasmir. Managemen Perbankan. Jakarta: PT Raja Grafindo Persada, 2000.

Veithzal, Islamic

Wiroso. Produk Perbankan Syariah. Jakarta: LPFE Usakti, 2011. 